\title{
Histopathological effects of galanin on reproductive hormones and reproductive organs of rabbit (Oryctolagus cuniculus)
}

\author{
Suleman Hussain Shah, Razia Iqbal, Mubashar Hussain*, Muhammad \\ Faheem Malik, Bilal Mukhtar and Muhammad Saqib Sajid \\ Department of Zoology, Faculty of Science, University of Gujrat, Punjab-Pakistan \\ *Corresponding author's email: dr.mubashar@uog.edu.pk \\ Citation \\ Suleman Hussain Shah, Razia Iqbal, Mubashar Hussain, Muhammad Faheem Malik, Bilal Mukhtar and Muhammad \\ Saqib Sajid. Histopathological effects of galanin on reproductive hormones and reproductive organs of rabbit \\ (Oryctolagus cuniculus). Pure and Applied Biology. Vol. 8, Issue 2, pp1523-1534. \\ http://dx.doi.org/10.19045/bspab.2019.80093
}

Received: $31 / 01 / 2019 \quad$ Revised: 03/05/2019

Accepted: 16/05/2019

Online First: 18/05/2019

\section{Abstract}

Effects of galanin, on reproductive hormones and histopathology of reproductive organs of rabbit was assessed by exposing adult rabbits to low, medium and high doses of $0.2,0.4$ and $0.8 \mu \mathrm{g} / \mathrm{ml}$ per kg body weight, respectively. Adult rabbits were reared and managed separately in cages $(2 \mathrm{x}$ $2 \times 2 \mathrm{~m}^{3}$ ) under controlled conditions of photoperiod (12 light: 12 dark) whereas temperature was maintained at $23 \pm 2{ }^{\circ} \mathrm{C}$. The measured quantities of Alfalfa fodder plant as a sole food was provided to all groups simultaneously with free access to water. The increase in the weight of testes and ovaries was recorded in males and females, respectively. The histopathological examination of gonads revealed no adverse effects, however, the significant differences in the levels of testosterone (4.21 ng/dl, 4.33ng/dl, $4.57 \mathrm{ng} / \mathrm{dl})$, estrogen $(123.33 \mathrm{pg} / \mathrm{ml}, 135.33 \mathrm{pg} / \mathrm{ml}, 151.33$ $\mathrm{pg} / \mathrm{ml})$ and progesterone $(196.33 \mathrm{ng} / \mathrm{ml}, 217.00 \mathrm{ng} / \mathrm{ml}, 229.33 \mathrm{ng} / \mathrm{ml})$ were recorded in the low, medium and high dose treated groups, respectively. The increase in the aggressive sexual behavior was noticed which correlated with the increase in the concentration of reproductive hormones. Galanin had no negative effects on the testes and the ovaries of rabbits but induced the production of reproductive hormones in addition to the increase in the weight of gonads.

Keywords: ELISA; Estrogen; Gonads; Testosterone

\section{Introduction}

Galanin (GAL) is a neuropeptide comprising of 29-30 amino acids found enormously throughout the endocrine system as well as in nervous system especially in the hypothalamus [1-6]. In order to perform various functions, galanin interacts with three kinds of G-protein coupled receptors viz. galanin receptor 1 (GalR1), galanin receptor 2 (GalR2) and galanin receptor 3 (GalR3) [7-
9]. GalR1 and GalR3 play its role through inhibition of Cyclic adenosine monophosphate/ protein kinase A (cAMP/PKA pathway, whereas GalR2 activates phospholipase-C [10].

Galanin primarily serves as a neurotransmitter for the transmission of impulses in the central as well as peripheral nervous system [11-13]. Recent studies has demonstrated that galanin (GAL) is involved 
in certain other processes like reproduction, gonadotropin-releasing hormone $(\mathrm{GnRH})$, luteinizing hormone (LH), LH-releasing hormone (LHRH) [14], uterine contraction regulation [15], regulation of estrogen [16], growth hormones [17], ingestion [18], enhanced prolactin secretion, growth of pituitary gland [11], inhibition of insulin secretion [9], vasopressin regulation, osmoregulation [19], muscle contraction, bowel movement [20], development, differentiation [21], maintenance of fat ingestion [22], skin, sweat glands [23], sensory reception [24], nociception, homeostasis of energy [25], appetite, seizure regulation [26], mood balance [8], inflammation, metabolism, acquired immunity, formation of bone and galial cell [10].

Galanin is involved in numerous pathological conditions like acute pancreatic necrosis [27], treatment of cancer [28], obesity [25], smoking [29], atrial pressure regulation [30], increased alcohol utilization [31], treatment of Alzheimer's disease, loss of memory, learning disabilities [32], epilepsy [33], emotions [34], anxiety [35], stress and depression [36]. Although galanin performs various functions, however, the objective of this work was to evaluate its effect on reproductive hormones and histopathology of reproductive organs of rabbit.

\section{Materials and methods}

\section{Experimental animal}

The male and female rabbits (Oryctolagus cuniculus) weighing approximately $1.0 \mathrm{~kg}$ to $1.5 \mathrm{~kg}$ were obtained from the Veterinary Research Institute, Lahore, Punjab, Pakistan. The rabbits were kept under photoperiod (12 hrs:12 hrs) and temperature $23 \pm 2{ }^{\circ} \mathrm{C}$ with free access to corresponding water and diet [37].

\section{Chemical and dose preparation}

Galanin (powder form) was purchased from Merck Sigma Aldrich, U.K. A measured quantity of galanin $1000 \mu \mathrm{g}$ was dissolved in
$1000 \mathrm{ml}$ water to prepare $1 \mu \mathrm{g} / 1 \mathrm{ml}$ dose. Low, medium and high doses were prepared through serial dilution method. All groups were treated with different doses of galanin $\mathrm{T}_{1}(0.2), \mathrm{T}_{2}(0.4)$ and $\mathrm{T}_{3}(0.8) \mu \mathrm{g} / \mathrm{ml}$ per $\mathrm{kg}$ body weight. The dose was administered daily for a month at an interval of $24 \mathrm{~h}$. Galanin doses were administered through jugular vein [38].

\section{ELISA and histopathology}

Blood samples were drawn from each group to perform ELISA after two hours of dose administration [39]. Blood sample collection was carried out by standard instructions [40]. In addition, six rabbits from each group were slaughtered on $10^{\text {th }}, 20^{\text {th }}$ and $30^{\text {th }}$ day of the $1^{\text {st }}$ dose administration followed by microtomy for histopathological examination of gonads. The blood samples were collected and serum was taken from red blood cells within 6 hours of sampling in gelatin serum tubes and preserved [41]. Blood samples were collected in gel tubes, centrifuged at $1600 \mathrm{Xg}$ for about $15 \mathrm{~min}$ at $4{ }^{\circ} \mathrm{C}$ and the plasma collected for further use and stored at $70{ }^{\circ} \mathrm{C}$.

\section{Weight of testes and ovaries}

The testes and ovaries were properly removed from the slaughtered rabbits, their weight was recorded with the help of electronic balance and histological examination of the sex organs was carried out [42].

\section{Tissue processing}

The tissue processing and staining was performed $[42,43]$ and to avoid the decomposition of tissues, they were put in Bouin's fixative for about 7-8 hours.

\section{Sectioning block}

The standard method was used for the sectioning of tissue and slide preparation [44]. Block cutting was done by using the microtome $[45,46]$.

\section{Experimental design and data analysis}

The study was laid down in Completely Randomized Design (CRD) with three 
replications. Adult breeding rabbits were divided into four groups, each group containing 18 rabbits with equal gender ratio. Data were subjected to statistical analysis and ANOVA was performed by using SPSS 21.

\section{Results}

\section{Effect of galanin on testes weight}

The weight of testes of male rabbits increased after the exposure to galanin. The data analysis indicated that the mean values for the treated group i.e. $\mathrm{T}_{1}(1.01 \mathrm{~g}, 1.06 \mathrm{~g}, 1.12$ $\mathrm{g}), \mathrm{T}_{2}(1.13 \mathrm{~g}, 1.17 \mathrm{~g}, 1.22 \mathrm{~g})$ and $\mathrm{T}_{3}(1.25 \mathrm{~g}$, $1.32 \mathrm{~g}, 1.39 \mathrm{~g})$ were significantly higher as compared to untreated group $\mathrm{T}_{\mathrm{o}}(0.74 \mathrm{~g}, 0.84$ $\mathrm{g}, 0.95 \mathrm{~g})$. Moreover, testes weight of male rabbits was high in treated group but regularly increased with respect to days and on $30^{\text {th }}$ day it was significantly higher as compared to $10^{\text {th }}$ day (Table 1 ).

\section{Effect of galanin on ovaries weight}

The weight of ovaries of female rabbits increased after the exposure to galanin. The statistical analysis revealed that mean values $\mathrm{T}_{1}(0.31 \mathrm{~g}, 0.34 \mathrm{~g}, 0.39 \mathrm{~g}), \mathrm{T}_{2}(0.42 \mathrm{~g}, 0.48 \mathrm{~g}$, $0.55 \mathrm{~g})$ and $\mathrm{T}_{3}(0.53 \mathrm{~g}, 0.61 \mathrm{~g}, 0.66 \mathrm{~g})$ were significantly higher as compared to untreated group $(0.20 \mathrm{~g}, 0.25 \mathrm{~g}, 0.28 \mathrm{~g})$ at $10^{\text {th }}, 20^{\text {th }}$ and $30^{\text {th }}$ days of experiment for low, medium and high doses, respectively. Moreover, maximum weight of ovaries of female rabbits increased in the high dose group at $30^{\text {th }}$ day (Table 2).

\section{Effect of galanin on testosterone}

The level of testosterone was elevated significantly. In addition, statistical analysis displayed that the mean values for each of the treated group i.e. $\mathrm{T}_{1}(3.43 \mathrm{ng} / \mathrm{dl}, 3.55 \mathrm{ng} / \mathrm{dl}$, $3.64 \mathrm{ng} / \mathrm{dl}), \mathrm{T}_{2}(3.79 \mathrm{ng} / \mathrm{dl}, 3.93 \mathrm{ng} / \mathrm{dl}, 4.01$ $\mathrm{ng} / \mathrm{dl})$ and $\mathrm{T}_{3}(4.21 \mathrm{ng} / \mathrm{dl}, 4.33 \mathrm{ng} / \mathrm{dl}, 4.57$ ng/dl) were comparatively higher than the control group $(1.70 \mathrm{ng} / \mathrm{dl}, 1.92 \mathrm{ng} / \mathrm{dl}, 2.15$ $\mathrm{ng} / \mathrm{dl})$. Moreover, testosterone hormone level was significantly higher in the treated group and regularly increased with respect to days (Table 3).
Furthermore, the results of current study were in confirmation with other researchers who suggested that galanin modulated sex hormones like testosterone and LH by stimulation of pituitary gland of rat [47]. Galanin significantly enhanced testosterone abundantly in rats [48]. Galanin increased the plasma level of testosterone in sannan goats [38].

\section{Effect of galanin on estrogen}

The levels of estrogen in female rabbit have risen significantly in dose response. The statistical data analysis depicted that mean values for each of the treated groups (low, medium and high dose) i.e. $\mathrm{T}_{1}(88.66 \mathrm{pg} / \mathrm{ml}$, $97.00 \mathrm{pg} / \mathrm{ml}, 114.33 \mathrm{pg} / \mathrm{ml}), \mathrm{T}_{2}$ (103.67 $\mathrm{pg} / \mathrm{ml}, 117.66 \mathrm{pg} / \mathrm{ml}, 136.33 \mathrm{pg} / \mathrm{ml})$ and $\mathrm{T}_{3}$ (123.33 pg/ml, $135.33 \mathrm{pg} / \mathrm{ml}, 151.33 \mathrm{pg} / \mathrm{ml}$ ) were comparatively higher than those of control group $(36.00 \mathrm{pg} / \mathrm{ml}, 40.67 \mathrm{pg} / \mathrm{ml}$, $52.67 \mathrm{pg} / \mathrm{ml}$ ). Estrogen hormone levels were highest in the high dose group at $30^{\text {th }}$ day (Table 4).

Our results were compatible with earliest studies involving intravenous administration of galanin in human beings in order to determine its effects on pituitary hormone (estrogen and growth hormone) secretion [49]. In 1987, it was revealed that galanin is a strong neuromodulator of LH and estrogen secretion [50]. Several studies revealed that galanin was a remarkable neuromodulator of reproductive hormones like $\mathrm{LH}$ and $\mathrm{FSH}$ secretion through GnRH-stimulation as well as the release of prolactin and oxytocine in mammals including human being, sheep, rodent like rat and mice. Thus, it might be a potent modulator of reproduction [51]. In 1998, an experiment on rats revealed that galanin regulated the plasma level of $\mathrm{LH}$ and estrogen. These findings suggest that galanin is a strong neuromodulator of $\mathrm{LH}$ and estrogen secretion in female rats [52].

\section{Effect of galanin on progesterone}

In addition, statistical data analysis reveals that the mean values for each of the treated 
group i.e. $\mathrm{T}_{1}(125.67 \mathrm{ng} / \mathrm{ml}, 148.33 \mathrm{ng} / \mathrm{ml}$, $167.00 \mathrm{ng} / \mathrm{ml}), \mathrm{T}_{2}(161.00 \mathrm{ng} / \mathrm{ml}, 179.67$ $\mathrm{ng} / \mathrm{ml}, 195.67 \mathrm{ng} / \mathrm{ml})$ and $\mathrm{T}_{3}(196.33 \mathrm{ng} / \mathrm{ml}$, $217.00 \mathrm{ng} / \mathrm{ml}, \quad 229.33 \mathrm{ng} / \mathrm{ml})$ are comparatively higher than those of control group (55.67 ng/ml, $71.00 \mathrm{ng} / \mathrm{ml}, 96.67$ $\mathrm{ng} / \mathrm{ml})$. Moreover, progesterone hormone level is enormously highest in high dose group at $30^{\text {th }}$ day (Table 5).

Our results were compatible with earliest studies including intravenous administration of galanin in rat in order to increase the level of LH by increasing the concentration of progesterone [50]. These findings suggest that galanin plays a vital role in the modulation of $\mathrm{LH}$ and progesterone secretion in female rats [52].

\section{Histopathology results}

At $10^{\text {th }}, 20^{\text {th }}$ and $30^{\text {th }}$ day, histological examination showed no difference in testes and ovaries both in galanin treated (low, medium and high) and untreated groups (control). The histopathological studies shown the normal tissue like sertoli cells were appeared in testes as well as oocytes and follicles were also present in ovaries (Figure $1-6)$.

Table 1. Effect of Galanin on Testes Weight (g) of Male Rabbits at $10^{\text {th }}, \mathbf{2 0}^{\text {th }}$, and $30^{\text {th }}$ Days (Mean \pm S.E.M)

\begin{tabular}{|c|c|c|c|c|}
\hline $\begin{array}{c}\text { Duration } \\
\text { (in days) }\end{array}$ & \multicolumn{4}{|c|}{ Treatment } \\
\hline & $\mathbf{T}_{\mathbf{0}}(\mathbf{C o n t r o l})$ & $\mathbf{T}_{\mathbf{1}}(\mathbf{0 . 2} \boldsymbol{\mu l})$ & $\left.\mathbf{T}_{\mathbf{2}} \mathbf{( 0 . 4} \boldsymbol{\mu l}\right)$ & $\mathbf{T}_{\mathbf{3}}(\mathbf{0 . 8} \boldsymbol{\mu} \mathbf{l})$ \\
\hline $\mathbf{1 0}$ & $0.74 \pm 0.018^{\mathrm{a}}$ & $1.01 \pm 0.020^{\mathrm{b}}$ & $1.13 \pm 0.029^{\mathrm{c}}$ & $1.25 \pm 0.027^{\mathrm{d}}$ \\
\hline $\mathbf{2 0}$ & $0.84 \pm 0.018^{\mathrm{a}}$ & $1.06 \pm 0.017^{\mathrm{b}}$ & $1.17 \pm 0.029^{\mathrm{c}}$ & $1.32 \pm 0.015^{\mathrm{d}}$ \\
\hline $\mathbf{3 0}$ & $0.95 \pm 0.015^{\mathrm{a}}$ & $1.12 \pm 0.011^{\mathrm{b}}$ & $1.22 \pm 0.026^{\mathrm{c}}$ & $1.39 \pm 0.018^{\mathrm{d}}$ \\
\hline
\end{tabular}

Means with different superscript in row are significantly different from one another $(\mathrm{p} \leq 0.05)$ Tukey's Test

Table 2. Effect of Galanin on Ovaries Weight (g) of Female Rabbits at $10^{\text {th }}, 20^{\text {th }}$, and $30^{\text {th }}$ Days (Mean \pm S.E.M)

\begin{tabular}{|c|c|c|c|c|}
\hline $\begin{array}{c}\text { Duration } \\
\text { (in days) }\end{array}$ & \multicolumn{4}{|c|}{ Treatment } \\
\hline & $\mathbf{T}_{\mathbf{0}}(\mathbf{C o n t r o l})$ & $\mathbf{T}_{\mathbf{1}}(\mathbf{0 . 2} \boldsymbol{\mu l})$ & $\mathbf{T}_{\mathbf{2}} \mathbf{( \mathbf { 0 . 4 } \boldsymbol { \mu l } )}$ & $\mathbf{T}_{\mathbf{3}}(\mathbf{0 . 8} \boldsymbol{\mu} \mathbf{)}$ \\
\hline $\mathbf{1 0}$ & $0.20 \pm 0.01^{\mathrm{a}}$ & $0.31 \pm 0.026^{\mathrm{b}}$ & $0.42 \pm 0.023^{\mathrm{c}}$ & $0.53 \pm 0.020^{\mathrm{d}}$ \\
\hline $\mathbf{2 0}$ & $0.25 \pm 0.023^{\mathrm{a}}$ & $0.34 \pm 0.026^{\mathrm{b}}$ & $0.48 \pm 0.021^{\mathrm{c}}$ & $0.61 \pm 0.015^{\mathrm{d}}$ \\
\hline $\mathbf{3 0}$ & $0.28 \pm 0.026^{\mathrm{a}}$ & $0.39 \pm 0.033^{\mathrm{b}}$ & $0.55 \pm 0.026^{\mathrm{c}}$ & $0.66 \pm 0.026^{\mathrm{d}}$ \\
\hline
\end{tabular}

Means with different superscript in row are significantly different from one another $(\mathrm{p} \leq 0.05)$ Tukey's Test

Table 3. Effect of Galanin on Testosterone Level (ng/dl) Of Male Rabbits at $10^{\text {th }}$ 20 $^{\text {th }}$, and $3^{\text {th }}$ Days (Mean \pm S.E.M)

\begin{tabular}{|c|c|c|c|c|}
\hline $\begin{array}{c}\text { Duration } \\
\text { (in days) }\end{array}$ & \multicolumn{4}{|c|}{ Treatment } \\
\hline & $\mathbf{T}_{\mathbf{0}}(\mathbf{C o n t r o l})$ & $\mathbf{T}_{\mathbf{1}}(\mathbf{0 . 2} \boldsymbol{\mu l})$ & $\mathbf{T}_{\mathbf{2}} \mathbf{( \mathbf { 0 . 4 } \boldsymbol { \mu l } )}$ & $\mathbf{T}_{\mathbf{3}}(\mathbf{0 . 8} \boldsymbol{\mu l})$ \\
\hline $\mathbf{1 0}$ & $1.70 \pm 0.052^{\mathrm{a}}$ & $3.43 \pm 0.046^{\mathrm{b}}$ & $3.79 \pm 0.083^{\mathrm{c}}$ & $4.21 \pm 0.067^{\mathrm{d}}$ \\
\hline $\mathbf{2 0}$ & $1.92 \pm 0.032^{\mathrm{a}}$ & $3.55 \pm 0.057^{\mathrm{b}}$ & $3.93 \pm 0.087^{\mathrm{c}}$ & $4.33 \pm 0.046^{\mathrm{d}}$ \\
\hline $\mathbf{3 0}$ & $2.15 \pm 0.035^{\mathrm{a}}$ & $3.64 \pm 0.071^{\mathrm{b}}$ & $4.01 \pm 0.072^{\mathrm{c}}$ & $4.57 \pm 0.090^{\mathrm{d}}$ \\
\hline
\end{tabular}

Means with different superscript in row are significantly different from one another $(\mathrm{p} \leq 0.05)$ Tukey's Test 
Table 4. Effect of Galanin on Estrogen Level $(\mathrm{pg} / \mathrm{ml})$ of Female Rabbits at $10^{\text {th }}, \mathbf{2 0}^{\text {th }}$, and $30^{\text {th }}$ Days (Mean \pm S.E.M)

\begin{tabular}{|c|c|c|c|c|}
\hline $\begin{array}{c}\text { Duration (in } \\
\text { days) }\end{array}$ & \multicolumn{4}{|c|}{ Treatment } \\
\hline & $\mathbf{T}_{\mathbf{0}}(\mathbf{C o n t r o l})$ & $\mathbf{T}_{\mathbf{1}}(\mathbf{0 . 2} \boldsymbol{\mu l})$ & $\mathbf{T}_{\mathbf{2}}(\mathbf{0 . 4} \boldsymbol{\mu} \mathbf{l})$ & $\mathbf{T}_{\mathbf{3}}(\mathbf{0 . 8} \boldsymbol{\mu l})$ \\
\hline $\mathbf{1 0}$ & $36.00 \pm 2.309^{\mathrm{a}}$ & $88.66 \pm 2.028^{\mathrm{b}}$ & $103.67 \pm 2.027^{\mathrm{c}}$ & $123.33 \pm 2.027^{\mathrm{d}}$ \\
\hline $\mathbf{2 0}$ & $40.67 \pm 2.028^{\mathrm{a}}$ & $97.00 \pm 2.309^{\mathrm{b}}$ & $117.66 \pm 2.028^{\mathrm{c}}$ & $135.33 \pm 2.028^{\mathrm{d}}$ \\
\hline $\mathbf{3 0}$ & $52.67 \pm 2.603^{\mathrm{a}}$ & $114.33 \pm 2.0278^{\mathrm{b}}$ & $136.33 \pm 1.763^{\mathrm{c}}$ & $151.33 \pm 2.028^{\mathrm{d}}$ \\
\hline
\end{tabular}

Means with different superscript in row are significantly different from one another $(\mathrm{p} \leq 0.05)$ Tukey's Test

Table 5. Effect of Galanin on Progesterone Level (ng/ml) of Female Rabbits at $10^{\text {th }}$, 20 $^{\text {th }}$, and $3^{\text {th }}$ Days (Mean \pm S.E.M)

\begin{tabular}{|c|c|c|c|c|}
\hline $\begin{array}{c}\text { Duration } \\
\text { (in days) }\end{array}$ & \multicolumn{4}{|c|}{ Treatment } \\
\hline & $\mathbf{T}_{\mathbf{o}}(\mathbf{C o n t r o l})$ & $\mathbf{T}_{\mathbf{1}}(\mathbf{0 . 2} \boldsymbol{\mu} \mathbf{l})$ & $\mathbf{T}_{\mathbf{2}}(\mathbf{0 . 4} \boldsymbol{\mu} \mathbf{l})$ & $\mathbf{T}_{\mathbf{3}}(\mathbf{0 . 8} \boldsymbol{\mu} \mathbf{l})$ \\
\hline $\mathbf{1 0}$ & $55.67 \pm 3.528^{\mathrm{a}}$ & $125.67 \pm 4.630^{\mathrm{b}}$ & $161.00 \pm 4.618^{\mathrm{c}}$ & $196.33 \pm 4.055^{\mathrm{d}}$ \\
\hline $\mathbf{2 0}$ & $71.00 \pm 6.429^{\mathrm{a}}$ & $148.33 \pm 4.055^{\mathrm{b}}$ & $179.67 \pm 2.9623^{\mathrm{c}}$ & $217.00 \pm 3.055^{\mathrm{d}}$ \\
\hline $\mathbf{3 0}$ & $96.67 \pm 4.631^{\mathrm{a}}$ & $167.00 \pm 4.619^{\mathrm{b}}$ & $195.67 \pm 2.906^{\mathrm{c}}$ & $229.33 \pm 2.028^{\mathrm{d}}$ \\
\hline
\end{tabular}

Means with different superscript in row are significantly different from one another $(\mathrm{p} \leq 0.05)$ Tukey's Test

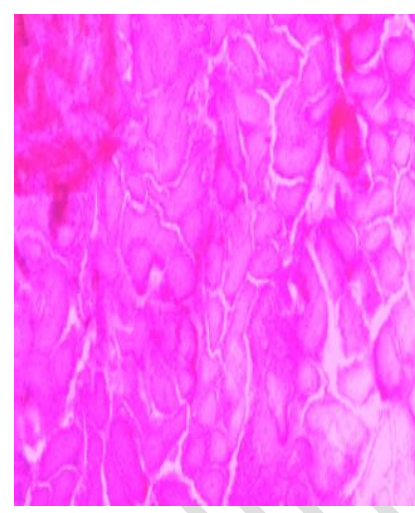

$\mathrm{T}_{1}$

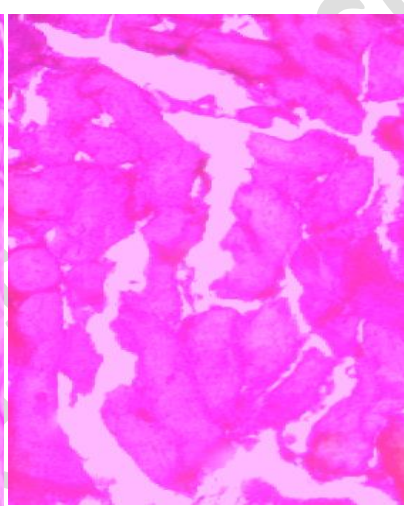

$\mathrm{T}_{2}$

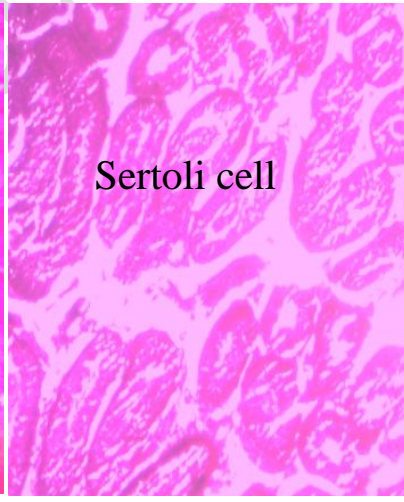

$\mathrm{T}_{3}$

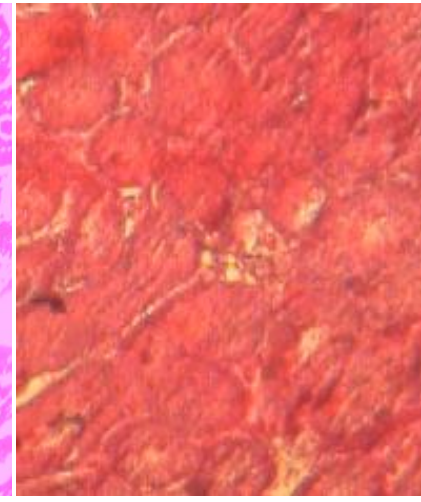

$\mathrm{T}_{\mathrm{o}}$

Figure 1. Shows Comparative Effects of Galanin on Histological Parameter of Testes between Group $T_{1}$ (Low), Group $T_{2}$ (Medium), Group $T_{3}$ (High) and Group $T_{0}$ (Control) at 100X Magnification Power under Light Microscopes at $10^{\text {th }}$ day 


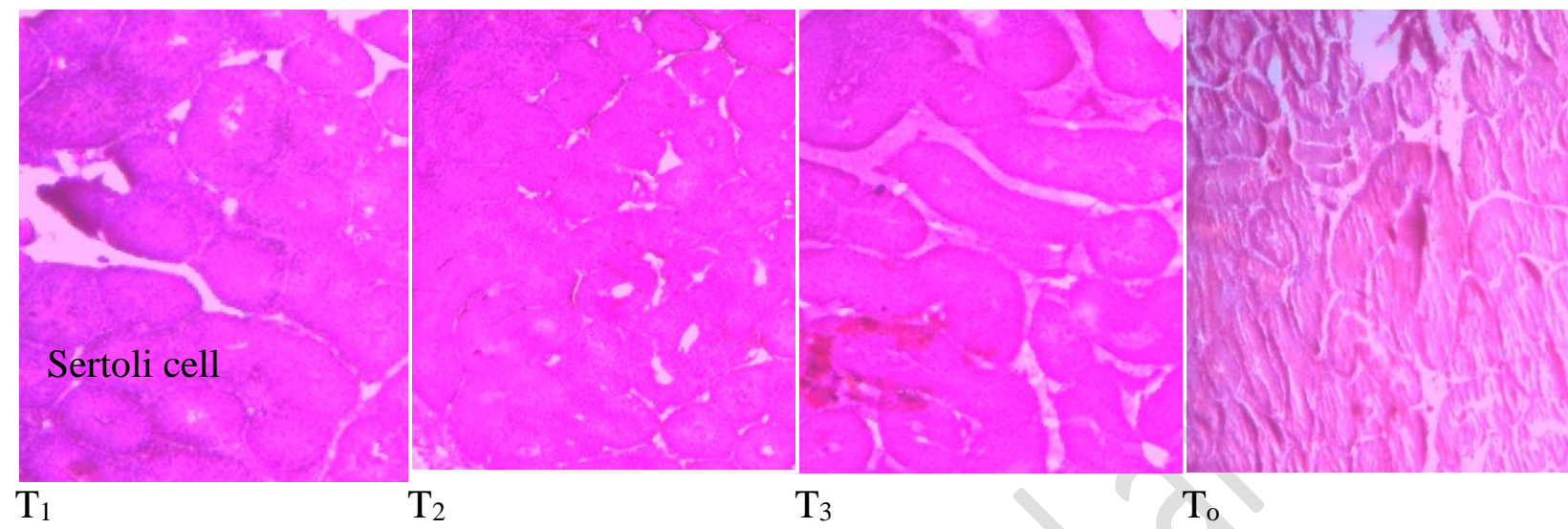

Figure 2. Shows Comparative Effects of Galanin on Histological Parameter of Testes between Group $\mathrm{T}_{1}$ (Low), Group $\mathrm{T}_{2}$ (Medium), Group $\mathrm{T}_{3}$ (High) and Group $\mathrm{T}_{\mathrm{o}}$ (Control) at 100X Magnification Power under Light Microscopes at $20^{\text {th }}$ day

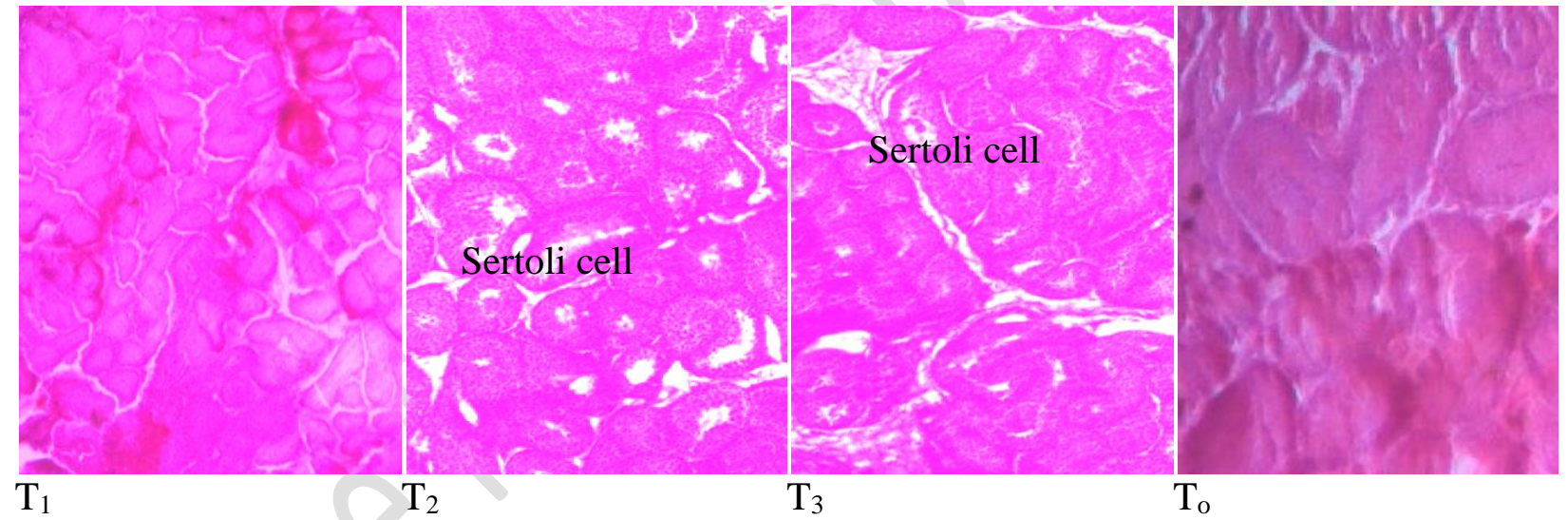

Figure 3. Shows Comparative Effects of Galanin on Histological Parameter of Testes between Group $T_{1}$ (Low), Group $T_{2}$ (Medium), Group $T_{3}$ (High) and Group $T_{0}$ (Control) at 100X Magnification Power under Light Microscopes at $30^{\text {th }}$ day 


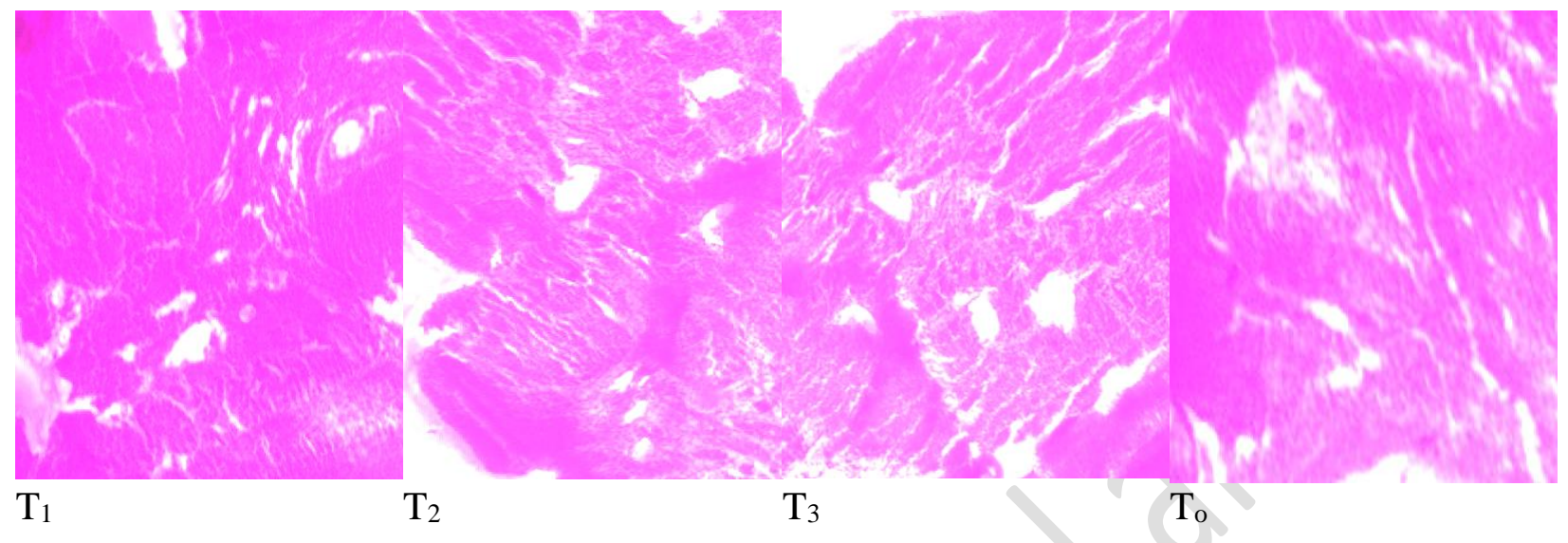

Figure 4. Shows Comparative Effects of Galanin on Histological Parameter of Ovaries between Group $T_{1}$ (Low), Group $T_{2}$ (Medium), Group $T_{3}$ (High) and Group $\mathbf{T}_{\mathbf{o}}$ (Control) at 100X Magnification Power under Light Microscopes at $10^{\text {th }}$ day

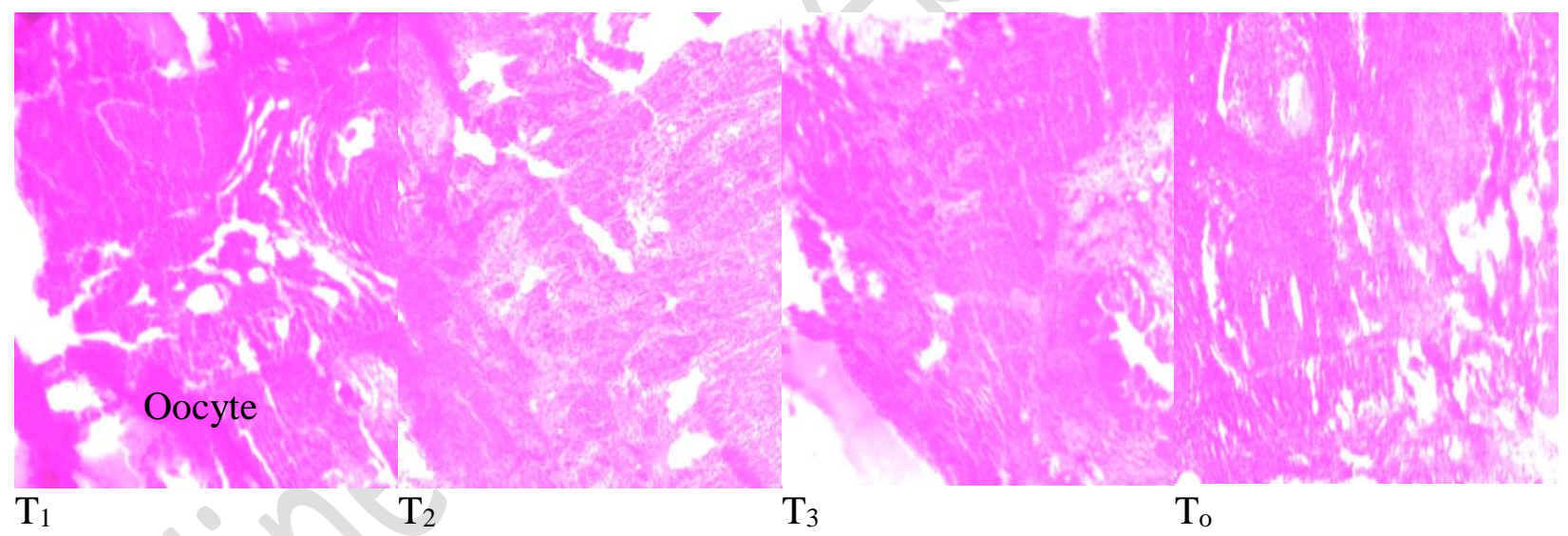

Figure 5. Shows Comparative Effects of Galanin on Histological Parameter of Ovaries between Group $T_{1}$ (Low), Group $T_{2}$ (Medium), Group T3 (High) and Group $\mathbf{T}_{\mathbf{o}}$ (Control) at 100X Magnification Power under Light Microscopes at $20^{\text {th }}$ day 


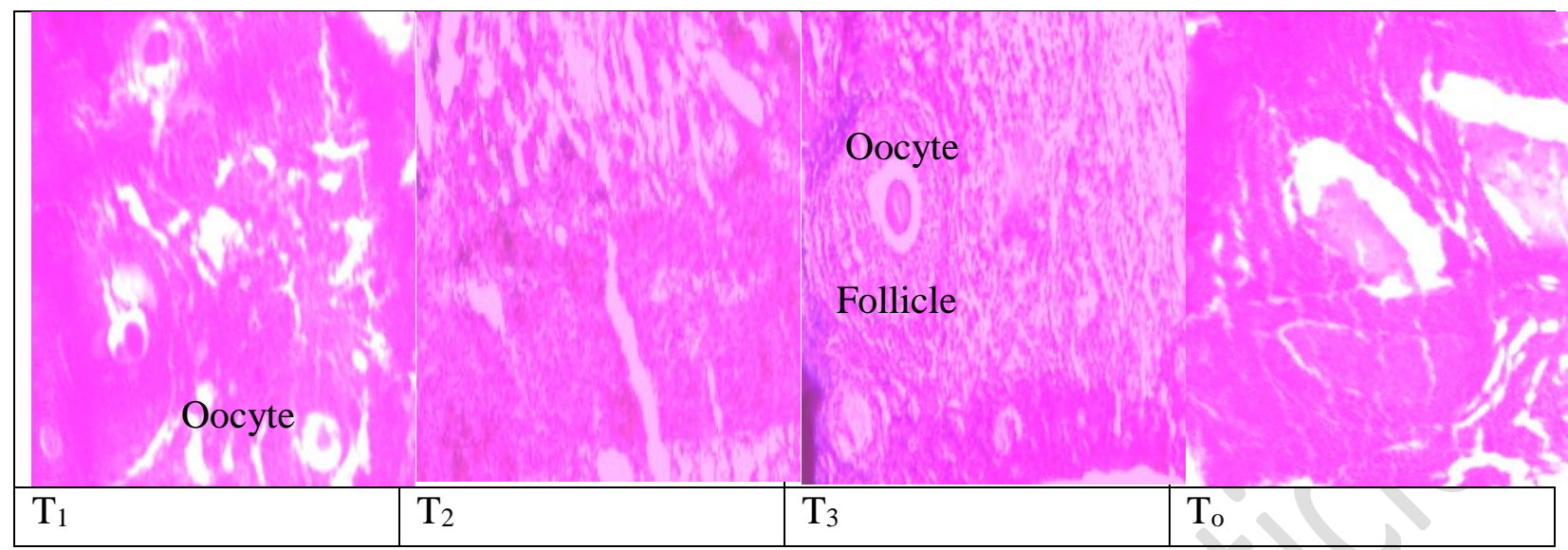

Figure 6. Shows Comparative Effects of Galanin on Histological Parameter of Ovaries between Group T1 (Low), Group T2 (Medium), Group T3 (High) and Group To (Control) at 100X Magnification Power under Light Microscopes at 30th day

\section{Discussion}

The findings of the current study suggested that galanin significantly modulated the reproductive hormone secretion i.e. testosterone in adult males and estrogen and progesterone in adult females. In addition, it was examined that testes and ovaries' weight was significantly increased in both male and female rabbits. However, the increase in testes' weight was relatively greater as compared to that of ovaries. Contrary to untreated group, an aggressive sexual behavior was observed in treated groups (male and female). Nevertheless, after dissection on day $10^{\text {th }}, 20^{\text {th }}$, and $30^{\text {th }}$ it was observed that there was no significant alteration or damage present in testes and ovaries of male and female rabbits respectively. On $30^{\text {th }}$ day, sertoli cell was prominent in testes as well as oocyte and follicles in ovaries of rabbits. Subsequently, the histological study of testes and ovaries showed that galanin had no pronounced negative effects on gonadal tissues of rabbits. Several studies revealed that galanin was a remarkable neuromodulator of reproductive hormones like testosterone, estrogen and progesterone secretion through $\mathrm{GnRH}-$ stimulation in mammals including human being [14], sheep [12], rodent like rat [47, 5355] and mice [56], pig [15] and sannan goat
[38]. These findings were compatible with those of prevailing study suggesting that galanin may be a potent modulator of reproduction. However, various studies revealed that the concentration of testosterone [51], estrogen [49] and progesterone [52] was elevated by galanin at high dose as compared to other doses.

\section{Conclusion}

Galanin has no adverse effects on reproductive organs but it stimulates the reproductive hormone secretion and induces aggressive sexual behavior in dose dependent manner. These findings suggest that galanin administration in animals of commercial importance may increase their reproductive performance. However, further studies are required by altering the model organism and by changing the galanin concentration since its effects may vary by trying different doses as well as from species to species.

\section{Authors' contributions}

Conceived and designed the experiments: $\mathrm{SH}$ Shah, R Iqbal, Performed the experiments: SH Shah, MS Sajid, Analyzed the data: MS Sajid, M Hussain \& MF Malik, contributed reagents/ materials/ analysis tools: SH Shah, B Mukhtar \& R Iqbal, Wrote the paper: B Mukhtar \& M Hussain \& SH Shah. 


\section{Acknowledgments}

The authors profess the diligence and meticulous support provided by the Laboratory staff of Department of Zoology, University of Gujrat.

\section{References}

1. Branchek TA, Smith KE, Gerald C \& Walker MW (2000). Galanin receptor subtypes. Trends in Pharmacol Sci 21: 109-117.

2. Bacon A, Holmes FE, Small CJ, Ghatei M, Mahoney S, Bloom S \& Wynick DB (2002). Transgenic over-expression of galanin in injured primary sensory neurons. Neuroreport 13: 2129-2132.

3. Belfer I, Hipp H, Knight C M, Evans C, Buzas B, Bollettino A, Albaugh B, Virkkunen M, Yuan Q, Max MB, Goldman D \& Enoch MA (2006). Association of galanin haplotypes with alcoholism and anxiety in two ethnically distinct populations. Mol Psychiatry 11(3): 301-311.

4. Hawes JJ, Brunzell DH, Narasimhaiah R, Lange U, David Wynick D \& Picciotto MR (2008). Galanin protects against behavioral and neurochemical correlates of opiate reward. Neuropsychopharmacol 33: 1864-1873.

5. Agasse F, Xapelli S, Coronas V, Christiansen SH, Rosa AI, Sardá-Arroyo L, Santos T, Ferreira R, Schitine C \& Harnois T (2013). Galanin promotes neuronal differentiation in murine subventricular zone cell cultures. Stem Cells Dev 22: 1693-1708.

6. Scanlon CS, Banerjee R, Inglehart RC, Liu M, Russo N, Hariharan A, Tubergen E. A. V., Corson, S. L., Asangani, I. A., Mistretta MC, Chinnaiyan AM \& Silva NJD (2015). Galanin modulates the neural niche to favour perineural invasion in head and neck cancer. Nat Commun 6: 6885.

7. Mitsukawa K, Lu X \& Bartfai T (2010). Galanin, galanin receptors, and drug targets. Molecular and Integrative Neurosciences Department, The Scripps Research Institute, 10550 North Torrey Pines Road, La Jolla, CA 92037, USA.

8. Brunner SM, Farzib A, Lockera F, Holuba BS, Drexelc M, Reichmannb F, Langa AA, Mayra JA, Vilchesd JJ, Navarrod X, Lange R, Sperk G, Holzer P \& Koflera B. (2014). GAL3 receptor KO mice exhibit an anxiety like phenotype. PNAS 111(19): 7138-7143.

9. Amisten $\mathrm{S}$, Atanes $\mathrm{P}$, Hawkes $\mathrm{R}$, Inmaculada Ruz-Maldonado I, Liu B, Parandeh F, Zhao M, Huang GC, Salehi A \& Persaud S J (2017). A comparative analysis of human and mouse islet Gprotein coupled receptor expression. King's College London, London, UK.

10. Lang R, Gundlach AL, Holmes FE, Hobson, SA, Wynick D, Hokfelt T \& Kofler B. (2015). Physiology, signaling, and pharmacology of galanin peptides and receptors: three decades of emerging diversity. Pharmacol Rev 67: 118-175.

11. Perumal P \& Vrontakis ME (2003). Transgenic mice over-expressing galanin exhibit pituitary adenomas and increased secretion of galanin, prolactin and growth hormone. Endocrinol 179: 145-154.

12. Whitelaw CM, Robinson JE, Chambers, GB, Hastie P, Padmanabhan V, Thompson RC \& Evans NP (2009). Expression of mRNA for galanin, galanin-like peptide and galanin receptors 1-3 in the ovine hypothalamus and pituitary gland: effects of age and gender. Reprod 137: 141-150.

13. Yue H, Fujita T \& Kumamoto E (2011). Biphasic modulation by galanin of excitatory synaptic transmission in substantia gelatinosa neurons of adult rat spinal cord slices. J. Neurophysiol 105: 2337-2349.

14. Fang P, He B, Shi M, Kong G, Dong X, Zhu Y, Bo P \& Zhang Z (2015). The regulative effect of galanin family 
members on link of energy metabolism and reproduction. Pepti 71: 240-249.

15. Okrasa S, Skowronski MT, Staszkiewicz, J, Kotwica G, Lakomy M \& Ziecik AJ (2003). The effects of estradiol on $\beta$ endorphin, $\mathrm{GnRH}$ and galanin content in the oviductand the uterus of ovariectomized gilts. Reprod biol 3(1): 63-80.

16. Vrontakis M, Schroedter I, Leite V \& Friesen HG (1993). Estrogen regulation and localization of galanin gene expression in the rat uterus. Biol Reprod 49: 1245-1250.

17. Murakami Y, Ohshima K, Mochizuki T \& Yanaihara N (1993). Effect of human galanin on growth hormone prolactin, and antidiuretic hormone secretion in normal men. The JJ Clin Endocrinol Metab 77(5): 1436-14381.

18. Bailey KR, Pavlova MN, Rohde AD, Hohmann JG \& Crawley JN (2007). Galanin receptor subtype 2 (GalR2) null mutant mice display an anxiogenic-like phenotype specific to the elevated plusmaze. Pharmacol Biochem Behav 86: 820.

19. Brewer A, Langel U \& Robinson JK (2005). Intracerebroventricular administration of galanin decreases free water intake and operant water reinforce efficacy in water restricted rats. Neuropept 39(2): 117-124.

20. Anselmi L, Stella SLJ, Brecha NC \& Sternini C (2009). Galanin inhibition of voltage-dependent $\mathrm{Ca}(2+)$ influx in rat cultured myenteric neurons is mediated by galanin receptor 1 . J Neurosci Res 87 : 1107-1114.

21. Perel Y, Amrein L, Dobremez E, Rivel J, Daniel JY \& Landry M (2002). Galanin and galanin receptor expression in neuroblastic tumours:correlation with their differentiation status. $\mathrm{Br} J$ Cancer 86: 117-122.
22. Davidson S, Lear M, Shanley L, Hing B, Baizan-Edge A, Herwig A, Quinn IP, Breen G, McGuffin P, Starkey A., Barrett P \& MacKenzie A (2011). Differential activity by polymorphic variants of a remote enhancer that supports galanin expression in the hypothalamus and amygdala: implications for obesity, depression and alcoholism. Neuropsychopharmacol 36: 2211-2221.

23. Bovell DL, Holub BS, Odusanwol O, Brodowicz B, Rauch I, Kofler B \& Lang $R$ (2013). Galanin is a modulator of eccrine sweat gland secretion. Exp Dermatol 22: 141-159.

24. Bacon A, Kerr NC, H, Holmes, FE, Gaston K \& Wynick D (2007). Characterization of an enhancer region of the galanin gene that directs expression to the dorsal root ganglion and confers responsiveness to axotomy. $J$ Neurosci 27(24): 6573-6580.

25. Sandoval-Alzate HF, Agudelo-Zapata Y, Gonzalez-Clavijo AM, Poveda NE, Espinel Pachon, CF, Escamilla-Castro JA, Marquez-Julio HL, Alvarado Quintero H, Rojas-Rodriguez FG, Arteaga-Diaz JM, Eslava-Schmalbach J H, Garces Gutierrez MF, Maria Vrontakis M, Castano JP, Luque RM, Dieguez, C. Nogueiras R \& Caminos JE (2016). Serum Galanin Levels in Young Healthy Lean and Obese Non Diabetic Men during an Oral Glucose Tolerance Test. Sci Rep 6: 31661.

26. Bulaj G, Green BR, Lee H, Robertson CR, White K, Zhang L, Sochanska M, Flynn SP, Scholl EA, Pruess TH, Smith MD \& White HS (2008). Design, synthesis, and characterization of highaffinity, systemically-active galanin analogues with potent anticonvulsant activities. J Med Chem 51(24): 80388047.

27. Bhandari M, Thomas A C, Hussey DJ, Li X, Jaya SP, Woods CM, Schloithe AC, 
Mayne GC, Carati CJ \& Toouli J (2010). Galanin mediates the pathogenesis of cerulein-induced acute pancreatitis in the mouse. Pancreas 39: 182-187.

28. Scanlon CS (2014). The role of galanin in perineural invasion of head and neck cancer; University of Michigan, pp.1162.

29. Gold AB, Wileyto EP, Lori A, Conti D, Cubells JF \& Lerman C (2012). Pharmacogenetic Association of the Galanin Receptor (GALR1) SNP rs2717162 with smoking Cessation. Neuropsychopharmacol 37: 1683-1688.

30. Abbott SBG \& Pilowsky PM (2009). Galanin microinjection into rostral ventrolateral medulla of the rat is hypotensive and attenuates sympathetic chemoreflex. Am J Physiol Regul Integr Comp Physiol 296: 1019-1026.

31. Ash BL, Quach T, Williams SJ, Lawrence AJ \& Djouma E (2014). Galanin-3 receptor antagonism by SNAP 37889 reduces motivation to selfadminister alcohol and attenuates cueinduced reinstatement of alcohol-seeking in rats. J Pharmacol Sci 125: 211-216.

32. Baraka A \& ElGhotny S (2010). Study of the effect of inhibiting galanin in Alzheimer's disease induced in rats. Eur J Pharmacol 641: 123-127.

33. Bartfai T, Lu X, Badie-Mahdavi H, Barr AM, Mazarati A, Hua X, Yaksh T, Haberhauer G, Ceide SC, Trembleau L, Somogyi L, Krock L \& Rebek J J (2004). Galmic, a nonpeptide galanin receptor agonist, affects behaviors in seizure, pain and forced-swim tests. PNAS 101(28): 10470-10475.

34. Holmes A, Kinney JW, Wrenn CC, Li Q, Yang RJ, Ma L, Vishwanath J, Saavedra MC, Innerfield CE, Jacoby AS, Shine J, Iismaa TP \& Crawley JN (2003). Galanin GAL-R1 receptor null mutant mice display increased anxiety-like behavior specific to the elevated plus-maze. Neuropsychopharmacol 28: 1031-1044.

35. Unschuld PG, Ising $M$, Roeske $D$, Erhardt A, Specht M, Kloiber S, Uhr M, Muller Myhsok B, Holsboer F \& Binder E B (2010). Gender-Specific association of galanin polymorphisms with hpa-axis dysregulation, symptom severity and antidepressant treatment response. Neuropsychopharmacol 35: 1583-1592.

36. Juhasz G, Hullam G, Eszlari N, Gonda X, Antald P, Anderson IM Hokfelt, TGM, Deakin JFW \& Bagdy G (2014). Brain galanin system genes interact with life stresses in depression-related phenotypes. P NAS 16666-16673.

37. Fang ZY, Lin R, Yuan B X, Yang GD, Liu Y \& Zhang H (2008). Tanshinone IIA down regulates the CD4 expression and diseases MMP-2activity on antherosclerosis induced by high fatty diet in rabbit. J ethnopharmacol 115(2): 217-222.

38. Shamsollahi M \& Asadi F (2014). Neurotransmitter effect of galanin on the mean plasma concentrations of growth hormone, triiodothyronine, thyroxine, and milk protein in dairy goats sannan. Endocrinol 2(3): 793-801.

39. Tietz NW (1995). Clinical Guide to Laboratory tests. 3rd Ed. W.B. Saunders, Co., Philadelphia, pp 509-512.

40. Hau J \& Van Hoosier GLV (2003). Handbook of laboratory animal science. USA; CRC Press, 69.

41. Raff H \& Sluss PM (2008). Pre-analytical issues for testosterone and estradiol assays. Steroids 73: 1297-1304.

42. Suvarna KS, Layton C \& Bancroft JD. (2012). Bancroft's theory and practice of histological technique e-book. Elsevier Health Sciences.

43. Jali PK, Donoghue $M$ \& Gadiwan $M$ (2015). A rapid manual processing technique for resource-limited small 
laboratories. J Oral Maxillofac. Pathol 19(3): 306.

44. Onozato ML, Hammond S, Merren M \& Yagi Y (2013). Evaluation of a completely automated tissue-sectioning machine for paraffin blocks. J Clin Pathol 66: 151-154.

45. Conn HJ (1969). Biological stains. 8th Ed. Lille, RD, Baltimore; Williams and Wikins.

46. Bancroft JD \& Stevens A (1990). Theory and practice of histological techniques 3rd Ed. Churchill livingstoneinc; Edinburgh London, Melbourne and New York.

47. Talebolhosseini M \& Khazali H (2017). Simultaneous effect of kisspeptin and galanin on serum luteinizing hormone and testosterone levels in male rats. GMJ 6(1): 23-29.

48. Pandit MA \& Saxena RN (2007). Galanin stimulate hCG induced testicular steroidogenesis in adulat not in immature male rat. Indian J Exp Biol 45: 333-337.

49. Giustina A, Licini M, Bussi AR, Girelli A, Pizzocolo G, Schettino M \& Negro Vilar A (1993). Effects of sex and age on the growth hormone response to galanin in healthy human subjects. J Clin Endocrinol Metab 76(5): 1369-1372.

50. Sahu A, Crowley WR, Tatemoto K, Balasubramaniam A \& Kalraa SP (1987). Effects of neuropeptide Y, NPY analog (norleucine4-NPY), galanin and neuropeptide $\mathrm{K}$ on LH release in ovariectomized (ovx) and ovx estrogen, progesterone-treated rats. Pept 8(5): 921926.

51. Lopez FJ, Merchenthaler I, Ching M, Wisniewski MG \& Negro-Vilar A (1991). Galanin: A hypothalamichypophysiotropic hormone modulating reproductive functions. Proc Nati Acad Sci 88: 4508-4512.

52. Leibowitz SF, Akabayashi A, Jesline T, Alexander \& Wang T (1998). Gonadal steroids and hypothalamic galanin and neuropeptide $\mathrm{Y}$ : role in eating behavior and body weight control in female rats. Endocrinol 139: 1771-1780.

53. Leiva LA \& Croxatto HB (1994). Comparison of the effect of hypothalamic neuropeptides upon luteinizing hormone secretion by cultured rat anterior pituitary cells. Biol Res 27: 113-121.

54. Niiro N, Nishimura J, Hirano K, Nakano H \& Kanaide H (1998). Mechanisms of galanin-induced contraction in the rat myometrium. Br J Pharmacol 124: 16231632.

55. Todd JF, Small CJ, Akinsanya KO, Stanley SA, Smith DM \& Bloom SR (1998). Galanin is a paracrine inhibitor of gonadotroph function in the female rat. Endo 139(10): 4222-4229.

56. Whitelaw CM, Robinson JE, Hastie PM, Padmanabhan V \& Evan NP (2012). Effects of cycle stage on regionalised galanin, galanin receptors 1-3, GNRH and GNRH receptor mRNA expression in the ovine Hypothalamus. $J$ Endocrinol 212: 353-361. 